\title{
Effect of Phosphorus on Nutrient Uptake of Japonica and Indica Rice
}

\author{
M. A. ISLAM ${ }^{1 *}$, M. R. ISLAM ${ }^{2}$ \& A. B. S. SARKER ${ }^{3}$ \\ ${ }^{1}$ Adaptive Research Division, Bangladesh Rice Research Institute, Regional Station-Sonagazi, \\ Feni, Bangladesh \\ ${ }^{2}$ Adaptive Research Division, Bangladesh Rice Research Institute, Gazipur, Bangladesh \\ ${ }^{3}$ Agronomy Division, Bangladesh Rice Research Institute, Gazipur, Bangladesh
}

\begin{abstract}
An experiment was conducted at the screen house of Tsukuba International Centre (TBIC), Japan to clarify the effect of phosphorus on nutrient absorption characteristics of a japonica (Nipponbare) and an indica (IR-28) rice variety. The experiment was conducted under submerged condition in subsoil of an Andisol, which had a high capacity of phosphate fixation. Levels of phosphorus were 100, 200, 500 and $800 \mathrm{~kg} \mathrm{P}_{2} \mathrm{O}_{5} \mathrm{ha}^{-1}$. The $P$ content in rice plant at different growth stages increased progressively with an increase of $P$ levels for both the varieties. With respect to $P$ content, varietal differences were minimal. But in the case of $N$ and $K$ content, IR-28 showed higher ability than Nipponbare. At maximum tillering stage, both the varieties showed negative co-relation between $P$ and $N$ uptake but at harvest stage, strong positive co-relation between $P$ and $N$ uptake was found for both the varieties. Both the varieties showed positive co-relation between $N$ and $K$ uptake at all the stages.
\end{abstract}

Key words: Andisol, IR-28, nipponbare, phosphorus, uptake.

\section{INTRODUCTION}

Rice is the staple food for the 140 million people of Bangladesh, and is grown here on around 10 million hectares. Most of the rice yield comes from high yielding variety (HYV) rice. Because of continuous growing of HYV rice and injudicious fertilizer management, many soils are getting exhausted. This is resulting in problems of $\mathrm{P}, \mathrm{K}$, and $\mathrm{S}$ deficiency in soils along with inherited $\mathrm{N}$ deficiency (Ali et al., 1997; Saleque et al., 1998a; Saleque et al., 1998b). Moreover, mineral fertilizers in this region are costly compared to the prices of rice. Thus, rice varieties with higher nutrient use efficiency (i.e. yield per unit nutrient absorbed) would be highly desirable.

Compared with nitrogen $(N)$ nutrition, phosphorus $(P)$ nutrition of rice plants has received little attention, because under favorable soil conditions the response of rice to $P$ fertilizer is far less marked than that to N. Phosphorus deficiency is likely to develop in many soils under intensive rice cultivation, and the use of improved varieties in rice production will increase the problem (IRRI, 1993). Rice varieties are known to differ in their ability to grow under low-P conditions (Neue, 1991). The more $\mathrm{P}$ efficient varieties may have internal and/ or external mechanisms that allow greater soil $\mathrm{P}$ extraction and grain yield. An understanding of the internal and external $\mathrm{P}$ efficiencies of modem varieties (MV) rice is very important in selection of varieties adaptable to $\mathrm{P}$ deficient conditions.

* Corresponding author: Principal Scientific Officer, BRRI, RS-Sonagazi, Feni, Cell: 01715414017, E-mail: atique63@yahoo.com

(C) 2008 School of Agriculture and Rural Development, Bangladesh Open University, All rights reserved. 


\section{A. Islam et al.}

Intensive wetland rice cultivation is a common farming practice in Asian countries like Bangladesh. With the expansion of irrigation facilities and the introduction of MV rice, the use of chemical fertilizers for rice production has increased substantially over the last two decades. However, rice farmers usually do not apply balanced doses of $\mathrm{N}, \mathrm{P}$, potassium $(\mathrm{K})$, and other fertilizers. Phosphorus fertilizers are seldom applied for rice although $\mathrm{P}$ removal from soil continues due to the intensive cultivation. Over the years, $\mathrm{P}$ deficiency in rice soils is being observed in many areas, which could be one of the reasons for low rice yields. Ali et al. (1997) reported that in many soils of Bangladesh available $\mathrm{P}$ was decreased substantially in 1995 than in 1965. In Bangladesh, P deficiency, especially under lowland rice cultivation, has been identified in the soils of Sonagazi and Motigonj of Feni (Fluvaquents), Barisal (Haplaquents), and Gazipur (Paleudults) (Saleque et al., 1999). Acute P deficiency unexpectedly decreases rice yield. It is very important point to determine the effect of phosphorus on different nutrient uptake at each growth stages of rice without reducing the percentage of ripened grains. The present experiment, was, therefore, undertaken to determine the effects of phosphorus on nutrient uptake pattern of rice.

\section{MATERIALS AND METHODS}

This experiment was conducted at the screen house of Tsukuba International Centre (TBIC), Japan during the 2000 growth season (April-August) in wooden boxes of $1 \mathrm{~m} \times 1 \mathrm{~m} \times 0.25 \mathrm{~m}$ size. Subsoil of an Andisol was used for the experiment, which had high capacity of phosphate fixation. The experimental soil had $\mathrm{pH}$ of 6.2 , organic $\mathrm{C}$ of $1.64 \%$, organic matter of $2.89 \%$, total nitrogen content of $0.18 \%$, available phosphate $0.13 \mathrm{mg} \mathrm{P}_{2} \mathrm{O}_{5} / 100 \mathrm{~g}$ dry soil, exchangeable potassium $82.7 \mathrm{mg}$ $\mathrm{K}_{2} \mathrm{O} / 100 \mathrm{~g}$ dry soil, exchangeable calcium $524.65 \mathrm{mg} \mathrm{CaO} / 100 \mathrm{~g}$ dry soil and exchangeable magnesium $81.89 \mathrm{mg} \mathrm{MgO/100} \mathrm{g} \mathrm{dry} \mathrm{soil.}$

Two hundred (200) litre air dried subsoil of Andisol were placed in each box. Before placing the soil in the box, fertilizer was mixed up with basal fertilizer. Four levels of phosphorus, viz. 100, 200, 500 and 800 $\mathrm{kg} \mathrm{P}_{2} \mathrm{O}_{5} \mathrm{ha}^{-1}$ were used in this experiment. Besides phosphorus fertilizer, nitrogen and potassium were applied in each test box at the rates of 120 and $110 \mathrm{~kg} \mathrm{ha}^{-1}$ as ammonium sulphate and potassium chloride, respectively. $\mathrm{N}$ and $\mathrm{K}$ were applied in two splits: basal and topdressing at panicle initiation stage. The recommended dose of zinc ( $\left.24 \mathrm{~kg} \mathrm{ZnSO}_{4} ; 7 \mathrm{H}_{2} \mathrm{O} \mathrm{ha}^{-1}\right)$ was dissolved in water and applied to the soil of boxes after levelling and just before the transplanting. The soil in each box was puddled by hand and then kept under submerged condition for three days and made ready for seedling transplanting. One japonica rice variety (Nipponbare) and one indica variety (IR-28) were used for this experiment. The experiment was laid out in a two factor randomized complete block design with three replications. On 17 May 2000, thirty day old seedlings were transplanted at $20 \times 20 \mathrm{~cm}$ spacing with two seedlings per hill.

Plant samples (one hill at each time) for dry matter were collected from different growth stages, viz. seedling stage, 30 days after transplanting (DAT), maximum tillering stage, panicle initiation stage, heading stage and harvesting stage (plant, grain). Content and uptake of phosphorus, nitrogen and potassium were measured at different growth stages. A portion of $0.20 \mathrm{~g}$ plant sample was digested with $\mathrm{H}_{2} \mathrm{SO}_{4}$ and $\mathrm{N}$ was determined after distillation with micro-Kjeldahl distillation apparatus (Yoshida et al., 1976). Another $0.20 \mathrm{~g}$ sample was digested with $\mathrm{HNO}_{3}-\mathrm{HClO}_{4}$ mixture (5:2). The phosphorus was determined by the colorimetric method and the potassium was determined by atomic absorption spectrophotometer. Straw and grain samples were also digested using a $\mathrm{HNO}_{3}-\mathrm{HClO}_{4}(5: 2)$ mixture and $P$ was determined colorimetrically in the digest (Yoshida et al., 1976).

All measurements were done in duplicate, and the data were analyzed by ANOVA using the statistical software IRRISTAT 3.0.

\section{RESULTS AND DISCUSSION}

\section{Effect on nutrient content}

\section{Phosphorus content}

Phosphorus content in the plant significantly increased with phosphorus levels (Table 1). The $\mathrm{P}$ content of rice plant at different growth stages increased progressively with an increase of phosphorus levels. For example, in case of Nipponbare at 30 DAT, the lowest P content of $2.52 \mathrm{mg} \mathrm{g}^{-1}$ dry weight (DW) was found at low level of phosphorus (100 kg $\left.\mathrm{P}_{2} \mathrm{O}_{5} \mathrm{ha}^{-1}\right)$, which increased consistently through 
the increasing $P$ levels to $3.48 \mathrm{mg} \mathrm{g}^{-1} \mathrm{DW}$ at high level of phosphorus (800 $\mathrm{kg} \mathrm{P}_{2} \mathrm{O}_{5} \mathrm{ha}^{-1}$ ). This trend continued up to harvest stage in both the varieties. In this case, varietal difference was only observed at 30 DAT. In this stage, P content of Nipponbare was higher than IR-28. This varietal difference was conspicuous, especially, in early growth stage of rice and this difference gradually became smaller in the later stage of rice growth. Different levels of phosphorus also affected the grain $\mathrm{P}$ content of rice. In IR-28, the grain P content was $2.46 \mathrm{mg} \mathrm{g}^{-1} \mathrm{DW}$ at low level of phosphorus, but it increased up to $2.96 \mathrm{mg} \mathrm{g}^{-1} \mathrm{DW}$ at $800 \mathrm{~kg} \mathrm{P}_{2} \mathrm{O}_{5} \mathrm{ha}^{-1}$. Varietal differences in grain $\mathrm{P}$ content were minimal. At harvest stage, the grain $\mathrm{P}$ content was much higher than that of the shoot. This may be due to the translocation of phosphorus from shoot to grain at the harvest stage (Hedley et. al., 1994).

Table 1. Phosphorus content ( $\mathrm{mg} \mathrm{g}^{-1}$ dry weight) at different growth stages

\begin{tabular}{|c|c|c|c|c|c|c|c|}
\hline \multirow[t]{2}{*}{ Variety } & \multirow{2}{*}{$\begin{array}{l}\text { Applied } \mathrm{P}_{2} \mathrm{O}_{5} \\
\left(\mathrm{~kg} \mathrm{ha}^{-1}\right)\end{array}$} & \multirow[t]{2}{*}{30 DAT } & \multirow{2}{*}{$\begin{array}{c}\text { Maximum } \\
\text { Tillering Stage }\end{array}$} & \multirow{2}{*}{$\begin{array}{c}\text { Panicle } \\
\text { Initiation Stage }\end{array}$} & \multirow{2}{*}{$\begin{array}{l}\text { Heading } \\
\text { Stage }\end{array}$} & \multicolumn{2}{|c|}{ Harvesting stage } \\
\hline & & & & & & Shoot & Grain \\
\hline \multirow[t]{4}{*}{ Nipponbare } & 100 & 2.52 & 1.72 & 1.86 & 1.51 & 0.70 & 2.80 \\
\hline & 200 & 2.66 & 2.22 & 2.05 & 1.67 & 0.58 & 2.76 \\
\hline & 500 & 2.90 & 2.45 & 2.17 & 1.80 & 0.75 & 2.88 \\
\hline & 800 & 3.48 & 2.40 & 2.28 & 1.94 & 0.79 & 2.98 \\
\hline \multirow[t]{4}{*}{ IR-28 } & 100 & 2.23 & 1.84 & 1.84 & 1.60 & 0.54 & 2.46 \\
\hline & 200 & 2.60 & 2.05 & 2.04 & 1.71 & 0.43 & 2.57 \\
\hline & 500 & 2.98 & 2.28 & 2.21 & 1.90 & 0.77 & 2.89 \\
\hline & 800 & 3.02 & 2.36 & 2.16 & 1.98 & 0.91 & 2.96 \\
\hline \multirow[t]{3}{*}{ Significance } & V & * & n.s. & n.s. & n.s. & n.s. & n.s. \\
\hline & $\mathrm{P}$ & ** & $\star *$ & * & $\star *$ & * & $\star \star$ \\
\hline & $V \times P$ & n.s. & n.s. & n.s. & n.s. & n.s. & n.s. \\
\hline
\end{tabular}

$\mathrm{V}, \mathrm{P}$ and $\mathrm{V} \times \mathrm{P}$ means variety, phosphorus levels and interaction, respectively.

${ }^{\star},{ }^{*}$ and n.s. indicate significant at $1 \%, 5 \%$ level and non-significant, respectively.

Phosphorus concentration in grain is reduced with its deficiency in the soil. A low P content in seeds would delay root growth and ultimately crop establishment especially under low soil $P$ conditions. A high content in the rice seeds allows an early root development independent of the soil P supply (Hedley et. al., 1994).

\section{Total nitrogen content}

Except varietal difference, nitrogen content was very similar in all the treatments of phosphorus levels (Table 2). At 30 DAT, no varietal difference was observed, but after this stage a difference in $\mathrm{N}$ content was clearly observed among the two varieties. Except the shoot at the harvest stage, from the maximum tillering stage to the heading stage, IR-28 showed significantly higher $\mathrm{N}$ content than Nipponbare. For example, nitrogen content was $2.56 \%$ at maximum tillering stage of IR-28, when phosphorus was applied at the rate of $100 \mathrm{~kg} \mathrm{ha}^{-1}$. But at this stage of Nipponbare, $\mathrm{N}$ content was $2.04 \%$, which is $0.52 \%$ lower than that of IR-28. There was no varietal difference in shoot $\mathrm{N}$ content at the harvest stage, but in grain, IR-28 showed higher $\mathrm{N}$ content than Nipponbare. This inherent capacity in N content of IR-28 may be useful traits for the breeding purposes.

Table 2. Total Nitrogen content (\%) at different growth stages

\begin{tabular}{|c|c|c|c|c|c|c|c|}
\hline \multirow[t]{2}{*}{ Variety } & \multirow{2}{*}{$\begin{array}{l}\text { Applied } \mathrm{P}_{2} \mathrm{O}_{5} \\
\left(\mathrm{~kg} \mathrm{ha}^{-1}\right)\end{array}$} & \multirow[t]{2}{*}{30 DAT } & \multirow{2}{*}{$\begin{array}{c}\text { Maximum } \\
\text { Tillering Stage }\end{array}$} & \multirow{2}{*}{$\begin{array}{c}\text { Panicle } \\
\text { Initiation Stage }\end{array}$} & \multirow{2}{*}{$\begin{array}{l}\text { Heading } \\
\text { Stage }\end{array}$} & \multicolumn{2}{|c|}{ Harvesting Stage } \\
\hline & & & & & & Shoot & Grain \\
\hline \multirow[t]{4}{*}{ Nipponbare } & 100 & 3.83 & 2.04 & 1.08 & 0.90 & 0.58 & 1.02 \\
\hline & 200 & 3.56 & 1.95 & 1.23 & 0.96 & 0.54 & 1.02 \\
\hline & 500 & 3.61 & 1.81 & 1.11 & 0.99 & 0.54 & 0.94 \\
\hline & 800 & 3.83 & 1.91 & 1.34 & 1.09 & 0.56 & 1.04 \\
\hline \multirow[t]{4}{*}{ IR-28 } & 100 & 3.65 & 2.56 & 1.91 & 1.41 & 0.52 & 1.25 \\
\hline & 200 & 3.76 & 2.52 & 1.75 & 1.35 & 0.47 & 1.21 \\
\hline & 500 & 3.70 & 2.11 & 1.64 & 1.33 & 0.59 & 1.36 \\
\hline & 800 & 3.58 & 1.98 & 1.34 & 1.33 & 0.59 & 1.25 \\
\hline \multirow[t]{3}{*}{ Significance } & $\mathrm{V}$ & n.s. & * & $\star \star$ & $\star \star$ & n.s. & $\star \star$ \\
\hline & $P$ & n.s. & n.s. & n.s. & n.s. & n.s. & n.s. \\
\hline & $\mathrm{V} \times \mathrm{P}$ & n.s. & n.s. & n.s. & n.s. & n.s. & n.s. \\
\hline
\end{tabular}

$\mathrm{V}, \mathrm{P}$ and $\mathrm{V} \times \mathrm{P}$ means variety, phosphorus levels and interaction, respectively.

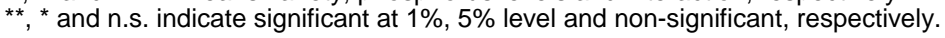




\section{A. Islam et al.}

\section{Potassium content}

There was no effect in potassium content due to the different levels of phosphorus application, but the varietal difference was very clear (Table 3 ). In almost all the stages, K content in IR-28 was higher than Nipponbare. After the panicle initiation stage, this difference was very conspicuous. When phosphorus was applied at the rate of $100 \mathrm{~kg} \mathrm{ha}^{-1}$, the potassium content was $43.37 \mathrm{mg} \mathrm{g}^{-1}$ dry weight in shoot at the harvesting stage of IR-28. But at this stage of Nipponbare, $\mathrm{K}$ content was only $26.13 \mathrm{mg} \mathrm{g}^{-1}$ which is much lower than that of IR-28. In case of grain $\mathrm{K}$ content, there was no considerable difference either between treatments or between varieties.

Table 3. Potassium content ( $\mathrm{mg} \mathrm{g}^{-1}$ dry weight) at different growth stages

\begin{tabular}{|c|c|c|c|c|c|c|c|}
\hline \multirow[t]{2}{*}{ Variety } & \multirow{2}{*}{$\begin{array}{l}\text { Applied } \mathrm{P}_{2} \mathrm{O}_{5} \\
\left(\mathrm{~kg} \mathrm{ha}^{-1}\right)\end{array}$} & \multirow[t]{2}{*}{30 DAT } & \multirow{2}{*}{$\begin{array}{c}\text { Maximum } \\
\text { Tillering Stage }\end{array}$} & \multirow{2}{*}{$\begin{array}{c}\text { Panicle } \\
\text { Initiation Stage }\end{array}$} & \multirow{2}{*}{$\begin{array}{l}\text { Heading } \\
\text { Stage }\end{array}$} & \multicolumn{2}{|c|}{ Harvesting Stage } \\
\hline & & & & & & Shoot & Grain \\
\hline \multirow[t]{4}{*}{ Nipponbare } & 100 & 51.90 & 44.10 & 44.57 & 29.92 & 26.13 & 13.77 \\
\hline & 200 & 53.27 & 45.60 & 45.13 & 29.34 & 27.03 & 13.34 \\
\hline & 500 & 52.00 & 44.17 & 40.77 & 29.42 & 25.47 & 13.88 \\
\hline & 800 & 53.00 & 46.37 & 43.80 & 30.06 & 25.43 & 13.53 \\
\hline \multirow[t]{4}{*}{ IR-28 } & 100 & 53.50 & 50.03 & 45.70 & 36.97 & 43.37 & 14.49 \\
\hline & 200 & 54.67 & 50.83 & 46.73 & 36.67 & 44.47 & 15.16 \\
\hline & 500 & 54.63 & 48.37 & 50.73 & 36.12 & 40.60 & 14.58 \\
\hline & 800 & 53.83 & 46.73 & 42.70 & 32.99 & 38.10 & 15.04 \\
\hline \multirow[t]{3}{*}{ Significance } & $\mathrm{V}$ & * & * & n.s. & $\star \star$ & $\star \star$ & n.s. \\
\hline & $\mathrm{P}$ & n.s. & n.s. & n.s. & n.s. & n.s. & n.s. \\
\hline & $\mathrm{V} \times \mathrm{P}$ & n.s. & n.s. & n.s. & n.s. & n.s. & n.s. \\
\hline
\end{tabular}

$\mathrm{V}, \mathrm{P}$ and $\mathrm{V} \times \mathrm{P}$ means variety, phosphorus levels and interaction, respectively.

$\star *, *$ and n.s. indicate significant at 1\%, $5 \%$ level and non-significant, respectively.

\section{Changes in nutrient uptake}

\section{Phosphorus}

In most cases, phosphorus absorption increased, with an increase in phosphorus application throughout the growth stages (Table 4). But in some cases, variation occurred. It may be due to the variation in dry matter production of the two varieties. The weight of dry matter of Nipponbare is more than that of IR-28. Therefore, the uptake pattern of phosphorus is almost similar to that of dry matter. Up to the panicle initiation stage, the amounts of phosphorus absorbed by Nipponbare were higher than IR-28 but this difference became smaller in the later stage of rice growing.

Table 4. Phosphorus uptake $\left(\mathrm{mg} \mathrm{hill}^{-1}\right)$ at different growth stages

\begin{tabular}{|c|c|c|c|c|c|c|c|c|}
\hline \multirow[t]{2}{*}{ Variety } & \multirow{2}{*}{$\begin{array}{c}\text { Applied } \\
\mathrm{P}_{2} \mathrm{O}_{5} \\
\left(\mathrm{~kg} \mathrm{ha}^{-1}\right)\end{array}$} & \multirow[t]{2}{*}{30 DAT } & \multirow{2}{*}{$\begin{array}{l}\text { Maximum } \\
\text { Tillering } \\
\text { Stage }\end{array}$} & \multirow{2}{*}{$\begin{array}{l}\text { Panicle } \\
\text { Initiation } \\
\text { Stage }\end{array}$} & \multirow{2}{*}{$\begin{array}{l}\text { Heading } \\
\text { Stage }\end{array}$} & \multicolumn{3}{|c|}{ Harvesting Stage } \\
\hline & & & & & & Shoot & Grain & Total \\
\hline \multirow[t]{4}{*}{ Nipponbare } & 100 & 21.5 & 36.5 & 65.8 & 104.4 & 31.3 & 76.3 & 107.5 \\
\hline & 200 & 23.5 & 38.9 & 52.7 & 98.7 & 32.5 & 98.9 & 131.4 \\
\hline & 500 & 21.7 & 41.0 & 62.0 & 99.0 & 45.8 & 114.8 & 160.6 \\
\hline & 800 & 25.7 & 48.0 & 68.6 & 99.6 & 39.4 & 95.1 & 134.5 \\
\hline \multirow[t]{4}{*}{ IR-28 } & 100 & 12.5 & 29.6 & 32.8 & 83.1 & 15.1 & 78.8 & 94.0 \\
\hline & 200 & 16.8 & 29.9 & 40.3 & 92.5 & 14.8 & 118.3 & 133.0 \\
\hline & 500 & 20.4 & 40.2 & 49.9 & 99.4 & 23.2 & 86.8 & 110.1 \\
\hline & 800 & 20.8 & 40.9 & 47.1 & 94.6 & 28.1 & 82.4 & 110.5 \\
\hline \multirow[t]{3}{*}{ Significance } & $\mathrm{V}$ & $\star \star$ & * & $\star \star$ & n.s. & $\star \star$ & n.s. & n.s. \\
\hline & $\mathrm{P}$ & $\star *$ & * & n.s. & n.s. & * & n.s. & n.s. \\
\hline & $\mathrm{V} \times \mathrm{P}$ & n.s. & n.s. & n.s. & n.s. & n.s. & n.s. & n.s. \\
\hline
\end{tabular}

$\mathrm{V}, \mathrm{P}$ and $\mathrm{V} \times \mathrm{P}$ means variety, phosphorus levels and interaction, respectively.

**, * and n.s. indicate significant at 1\%, $5 \%$ level and non-significant, respectively. 


\section{Nitrogen}

There was no effect on nitrogen absorption due to the application of different levels of phosphorus (Table 5). But in some stages of growth, varietal difference was observed. At 30 DAT, nitrogen uptake of Nipponbare was higher than IR-28 but at the heading stage, the reverse situation occurred. In this stage, IR-28 showed higher uptake of $\mathrm{N}$ than Nipponbare. At harvest stage, $\mathrm{N}$ uptake by shoot was higher in Nipponbare but in grains it was higher in IR-28.

Table 5. Nitrogen uptake $\left(\mathrm{mg} \mathrm{hill}^{-1}\right)$ at different growth stages

\begin{tabular}{|c|c|c|c|c|c|c|c|c|}
\hline \multirow[t]{2}{*}{ Variety } & \multirow{2}{*}{$\begin{array}{c}\text { Applied } \mathrm{P}_{2} \mathrm{O}_{5} \\
\left(\mathrm{~kg} \mathrm{ha}^{-1}\right)\end{array}$} & \multirow[t]{2}{*}{30 DAT } & \multirow{2}{*}{$\begin{array}{c}\text { Maximum } \\
\text { Tillering Stage }\end{array}$} & \multirow{2}{*}{$\begin{array}{c}\text { Panicle } \\
\text { Initiation Stage }\end{array}$} & \multirow{2}{*}{$\begin{array}{l}\text { Heading } \\
\text { Stage }\end{array}$} & \multicolumn{3}{|c|}{ Harvesting Stage } \\
\hline & & & & & & Shoot & Grain & Total \\
\hline \multirow[t]{4}{*}{ Nipponbare } & 100 & 323.2 & 434.5 & 379.3 & 621.2 & 270.3 & 279.1 & 552.4 \\
\hline & 200 & 312.2 & 343.4 & 316.4 & 566.4 & 295.7 & 354.9 & 653.5 \\
\hline & 500 & 268.9 & 315.0 & 331.0 & 549.6 & 324.5 & 369.4 & 693.9 \\
\hline & 800 & 281.3 & 383.1 & 404.6 & 562.1 & 281.9 & 330.5 & 612.4 \\
\hline \multirow[t]{4}{*}{ IR-28 } & 100 & 203.0 & 409.9 & 326.8 & 711.1 & 142.7 & 400.3 & 543.0 \\
\hline & 200 & 243.2 & 380.2 & 341.1 & 725.8 & 155.3 & 535.0 & 690.2 \\
\hline & 500 & 253.1 & 365.0 & 367.7 & 690.8 & 178.6 & 407.0 & 585.7 \\
\hline & 800 & 245.7 & 343.2 & 293.4 & 618.1 & 180.7 & 337.9 & 518.6 \\
\hline \multirow[t]{3}{*}{ Significance } & $\mathrm{V}$ & $\star \star$ & n.s. & n.s. & $\star$ & $\star *$ & $\star$ & n.s. \\
\hline & $\mathrm{P}$ & n.s. & n.s. & n.s. & n.s. & n.s. & n.s. & n.s. \\
\hline & $V \times P$ & n.s. & n.s. & n.s. & n.s. & n.s. & n.s. & n.s. \\
\hline
\end{tabular}

$\mathrm{V}, \mathrm{P}$ and $\mathrm{V} \times \mathrm{P}$ means variety, phosphorus levels and interaction, respectively.

**, * and n.s. indicate significant at 1\%, $5 \%$ level and non-significant, respectively.

\section{Potassium}

In case of potassium absorption, almost the same phenomenon as $\mathrm{N}$ absorption was happened (Table 6). Here, no effect of phosphorus levels was observed. At 30 DAT and the panicle initiation stage, varietal differences were happened. In these two stages, potassium absorption of Nipponbare was higher than IR-28.

Table 6. Potassium uptake $\left(\mathrm{mg} \mathrm{hill}^{-1}\right)$ at different growth stages

\begin{tabular}{|c|c|c|c|c|c|c|c|c|}
\hline \multirow[t]{2}{*}{ Variety } & \multirow{2}{*}{$\begin{array}{c}\text { Applied } \mathrm{P}_{2} \mathrm{O}_{5} \\
\left(\mathrm{~kg} \mathrm{ha}^{-1}\right)\end{array}$} & \multirow[t]{2}{*}{30 DAT } & \multirow{2}{*}{$\begin{array}{c}\text { Maximum } \\
\text { Tillering Stage }\end{array}$} & \multirow{2}{*}{$\begin{array}{c}\text { Panicle } \\
\text { Initiation Stage }\end{array}$} & \multirow{2}{*}{$\begin{array}{l}\text { Heading } \\
\text { Stage }\end{array}$} & \multicolumn{3}{|c|}{ Harvesting Stage } \\
\hline & & & & & & Shoot & Grain & Total \\
\hline \multirow{4}{*}{ Nipponbare } & 100 & 438.7 & 932.5 & 1565.7 & 2050.5 & 1220.0 & 374.1 & 1594.2 \\
\hline & 200 & 471.2 & 802.8 & 1157.2 & 1737.2 & 1499.0 & 481.9 & 1980.9 \\
\hline & 500 & 388.2 & 752.8 & 1212.9 & 1661.9 & 1546.7 & 551.2 & 2098.0 \\
\hline & 800 & 390.0 & 930.9 & 1319.9 & 1559.5 & 1271.9 & 433.9 & 1705.9 \\
\hline \multirow[t]{4}{*}{ IR-28 } & 100 & 299.5 & 801.9 & 798.7 & 1907.1 & 1179.7 & 465.9 & 1645.7 \\
\hline & 200 & 352.9 & 754.0 & 918.9 & 1971.5 & 1551.5 & 712.8 & 2264.3 \\
\hline & 500 & 374.6 & 844.4 & 1156.4 & 1895.4 & 1224.3 & 438.5 & 1662.9 \\
\hline & 800 & 369.6 & 801.3 & 937.0 & 1603.7 & 1178.7 & 401.4 & 1580.2 \\
\hline \multirow[t]{3}{*}{ Significance } & $\mathrm{V}$ & $\star \star$ & n.s. & ** & n.s. & n.s. & n.s. & n.s. \\
\hline & $\mathrm{P}$ & n.s. & n.s. & n.s. & n.s. & n.s. & n.s. & n.s. \\
\hline & $\mathrm{V} \times \mathrm{P}$ & $\star$ & n.s. & n.s. & n.s. & n.s. & n.s. & n.s. \\
\hline
\end{tabular}

$\mathrm{V}, \mathrm{P}$ and $\mathrm{V} \times \mathrm{P}$ means variety, phosphorus levels and interaction, respectively.

**, * and n.s. indicate significant at 1\%, $5 \%$ level and non-significant, respectively.

\section{Relationships among N, P and K uptake at different growth stages}

At the maximum tillering stage, both the varieties showed negative correlation between $\mathrm{P}$ and $\mathrm{N}$ uptake (Table 7). Here the relationship of IR-28 was very high $(r=-0.865)$ but for Nipponbare it was very low $(r=-0.182)$. At the heading stage, Nipponbare and IR-28 showed a reverse relationship from each other (Table 7). In this stage, Nipponbare showed a strong positive correlation $(r=0.965)$ but IR-28 continued negative relationship, although the $r$-value was lower $(r=$ - 0.351) than the maximum tillering stage. At the harvest stage, both the varieties showed strong positive correlation between $\mathrm{P}$ and $\mathrm{N}$ uptake (Table 7). 
M. A. Islam et al.

Table 7. Relationships of $N$ and $K$ uptake with $P$ uptake in rice varieties at different growth stages

\begin{tabular}{|c|c|c|c|c|}
\hline \multirow[t]{2}{*}{ Growth stages } & \multicolumn{2}{|c|}{ Var. Indica (IR-28) } & \multicolumn{2}{|c|}{ Var. Japonica (Nipponbare) } \\
\hline & Equation & rvalue* & Equation & rvalue* \\
\hline \multicolumn{5}{|c|}{ Relationship between $\mathrm{P}$ and $\mathrm{N}$ uptake } \\
\hline a. Maximum tillering stage & $Y=-3.89 x+511.14$ & -0.685 & $Y=-1.90 x+447.27$ & -0.182 \\
\hline b. Heading stage & $Y=-2.45 x+913.14$ & -0.351 & $Y=11.54 x-584.01$ & 0.965 \\
\hline c. Harvesting stage & $Y=3.96 x+140.57$ & 0.839 & $Y=2.60 x+280.42$ & 0.935 \\
\hline \multicolumn{5}{|c|}{ Relationship between $\mathrm{P}$ and $\mathrm{K}$ uptake } \\
\hline a. Maximum tillering stage & $Y=3.95 x+661.37$ & 0.669 & $Y=3.99 x+690.52$ & 0.217 \\
\hline b. Heading stage & $Y=-5.26 x+2331.3$ & -0.220 & $Y=70.63 x-5340.7$ & 0.886 \\
\hline c. Harvesting stage & $Y=16.97 x-111.8$ & 0.853 & $Y=9.16 x+621.63$ & 0.848 \\
\hline
\end{tabular}

$\star_{r}=$ Correlation co-efficient

In the case of $\mathrm{P}$ and $\mathrm{K}$ uptake at the maximum tillering stage (Table 7), the situation has been changed completely from that of $P$ and $N$ at maximum tillering stage. Here both the varieties showed positive correlation but it was negatively correlated for $\mathrm{P}$ and $\mathrm{N}$ at the same stage. At the heading stage (Table 7), both the varieties showed a similar trend of relationship between $\mathrm{P}$ and $\mathrm{K}$ which was found for $\mathrm{P}$ and $\mathrm{N}$ at the heading stage. Finally at the harvest stage (Table 7 ), both the varieties were positively correlated for $\mathrm{P}$ and $\mathrm{K}$ uptake.

\section{CONCLUSION}

The phosphorus content of japonica and indica rice varieties increased progressively with an increase of applied $\mathrm{P}$ levels but did not show any effect on $\mathrm{N}$ and $\mathrm{K}$ content. Varietal difference was minimal for $\mathrm{P}$ uptake but this difference was clear for $\mathrm{N}$ and $\mathrm{K}$ content. IR-28 showed higher $\mathrm{N}$ and $\mathrm{K}$ uptake ability than Nipponbare. Soil $\mathrm{P}$ deficiency may be responsible for $\mathrm{P}$ deficiency in grain and it may cause $P$ deficiency in the human diet. Rice varieties with internal and external $P$ efficiencies may be useful for breeding purpose to develop $\mathrm{P}$ deficient tolerant rice varieties.

\section{ACKNOWLEDGEMENTS}

The authors are grateful to the government of Japan and Bangladesh Rice Research Institute (BRRI) for financial support and giving the opportunity to carry out this experiment.

\section{LITERATURE CITED}

Ali, M. M. Shahid, S. M. Kubota, D. Masunage, T. and Wakatsuki, T. 1997. Soil degradation during the period 1967-1995 in Bangladesh. II. Selected chemical characters. Soil Sci Plant Nutri 43, 879-890.

Hedley, M. I., Kirk, G. J. D. and Santos, M. B. 1994. Phosphorus efficiency and the forms of soil phosphorus utilized by upland rice cultivars. Plant Soil 158, 53-62.

IRRI (International Rice Research Institute). 1993. "Rice Research in a Time of Change: IRRI's MediumTerm Plan for 1994-1998". International Rice Research Institute, Manila, Philippines. 79 pp.

Neue, H. N. 1991. Adverse soil tolerance mechanisms and screening techniques. In "Rice Production on Acid Soils of the Tropics" (P. Deturck and F. N. Ponnamperuma, Eds.), Institute of Fundamental Studies, Kandy. pp. 243-250.

Saleque, M. A., Abedin, M. J., Panaullah, G. M. and Bhuiyan, N. I. 1998a. Yield and phosphorus efficiency of some lowland rice varieties at different levels of soil-available phosphorus. Commun. Soil Sci Plant Anal 29, 2905-2916.

Saleque, M. A., Saha, P. K., Panaullah, G. M. and Bhuiyan, N. I. 1998b. Response of wetland rice to potassium in farmers' fields of the Barind tract of Bangladesh. J Plant Nutri 21, 39-47.

Saleque, M. A., Zaman, S. K., Hasan, M., Kabir M. S. and Panaullah, G. M. 1999. Determination of critical level of phosphorus in rice soils by statistical procedure. Progress Agric 10, 229-235.

Yoshida, S., Forno, D. A., Cock, J. H. and Gomez, K. A. 1976. "Laboratory Manual for Physiological Studies of Rice" (Third Edn.) International Rice Research Institute, Manila, Philippines. pp.14-22. 